\title{
Evaluation of antibacterial activity of cinnamon and ginger extracts against vancomycin-resistant Staphylococcus aureus isolated from nose of food handlers in restaurants and cafeterias
}

\author{
Uday Abdul-Reda Hussein
}

Ph.D. Pharmacology

\section{Department of Clinical Laboratory Science / College of Pharmacy / Thi-Qar University/ Iraq}

\begin{abstract}
:
Background: Food handlers are the main source of Staphylococcal food poisoning in developed countries.

Objective: The aim of this study was to determine the prevalence of the nasal carriage of vancomycin resistant Staphylococcus aureus among food handlers in restaurants and cafeterias, and to evaluate of antibacterial activity of cinnamon and ginger extracts against these bacteria.
\end{abstract}

Material and Methods: A total of 100 nasal swabs were collected from healthy food handlers and analyzed for Staphylococcus aureus, methicillin resistant Staphylococcus aureus (MRSA) and vancomycin resistant Staphylococcus aureus (VRSA) using standard methods. Aqueous and ethanolic extracts of each plant were prepared by using a Soxhalet apparatus and the antibacterial activities of these extracts against VRSA were determined by using agar well diffusion method.

Results: of 100 nasal swabs, 30 (30\%) isolates were Staphylococcus aureus, among which $25(83.3 \%)$ isolates were MRSA, and $20(80 \%)$ isolates among MRSA were VRSA. Both plant extracts showed potent antibacterial activity against VRSA. Cinnamon extracts showed higher antibacterial activity when compared with ginger extracts, whereas ethanolic extract of each plant was more effective than that of aqueous extract.

Conclusion: This study revealed a relatively high prevalence rate of VRSA nasal carriage among food handlers. Cinnamon and ginger are rich source of antimicrobial compounds 
which can be used as natural food preservatives and to treat infections caused by these bacteria .

Keywords: Food handlers, Staphylococcus aureus, MRSA, VRSA, Nasal carriage, Cinnamon, Ginger and Antibacterial activity.

\section{INTRODUCTION:}

Foodborne diseases are one of the major health problems throughout the world that can be affected about $30 \%$ of the population in developed countries each year. Staphylococcus aureus ( $S$. aureus) is the most foodborne pathogen which naturally colonizes the mucous membranes of anterior nares of healthy people. About $10-50 \%$ of people are carrier of both methicillin resistant and sensitive $S$. aureus (MRSA and MSSA) ${ }^{[1]}$.

Nasal carriage of $S$. aureus among food handlers working in restaurants and cafeterias are the main source of food contamination and food poisoning the Staphylococcal food poisoning considered as the most economically important diseases resulted from ingestion of food containing enterotoxins produced by some species of staphylococci which characterized by sudden onset of symptoms, including; nausea, vomiting, abdominal cramps, and diarrhea ${ }^{[3,4]}$.

\section{Staphylococcus}

aureus infections may lead to high morbidity and mortality because their ability for developing resistance quickly and successfully to antibiotics via a mechanism that involves acquisition and transfer of antibiotic resistance plasmids, as well as possession of intrinsic resistance mechanisms .Therefore, multidrug resistant $S$. aureus has been recognized as a persistent nosocomial and community acquired pathogen responsible for a several diseases, including endocarditis, osteomyelitis, toxic-shock syndrome, pneumonia, food poisoning and carbuncles. These infections can occur in wounds ,skin, burns, eyes, bones, heart or blood and other sites of the body ${ }^{[5]}$.In addition, this bacteria has a capacity to evolve different mechanisms of resistance against most antimicrobial agents like methicillin and vancomycin which continuously develop parallel with the drugs developed against it ${ }^{[6,7,8]}$. Vancomycin resistant $S$. aureus (VRSA) is clinical isolate of methicillin resistant Staphylococcus

aureus 
(MRSA) which shows in vitro non susceptibility to vancomycin [9]. Increasing failure of chemotherapeutics and antibiotic resistance exhibited by $S$. aureus especially VRSA has led to screen several medicinal plants for their potential antimicrobial activity ${ }^{[10]}$.

Plants have been a rich source of medicines because they produce wide array of bioactive molecules, most of which probably evolved as chemical defense against predation or infection. Herbs and spices are well known for their preservative and medicinal value as well as for boosting the flavor, color and aroma of the food. Therefore, the global food industries used spices as natural food preservatives instead of chemical preservatives due to increase occurrence of pathogenic strains resistance against these chemical compound $^{[11,12]}$.

\section{Cinnamon}

(Cinnamon

Zeylanicum) is a tropical evergreen tree grows in India and East Asia, used for the preparation of different types of chocolate, beverages, spicy candies and liquors. In addition cinnamon has been employed in traditional herbal medicine to treat a variety of health conditions including, diabetes , gastrointestinal disorders and urinary infections, it has also been used as antimicrobial, anti- inflammatory, antioxidant , antimutagenic and as neuroprotective agent ${ }^{[13,14,15,16]}$.

Ginger (Zingiber officinale) is one of the world's best known spices belongs to Zingiberaceae family, grows in Southeast Asia and cultivated in other countries like India. Ginger commonly used as flavoring agent and cooking spice. It has a several pharmacological activities such as antibacterial, antioxidant, anti-inflammatory, antidiabetic, anticarcinogenic and hepatoprotective activities, it has also been recommended to improve gastrointestinal illnesses, immunologic dysfunction and hypertension ${ }^{[17,18,19,20]}$.

\section{MATERIALS AND METHODS:}

Collection and preparation of plant extracts:

Cinnamon barks and ginger rhizomes were purchased and collected from the local market of Al-Nasiriya city, Iraq. The plants were cleaned and washed well in sterile distilled water and dried at room temperature, then milled into fine powder using an electric blender. One hundred grams $(100 \mathrm{~g})$ of each powdered plant material were extracted separately with $500 \mathrm{~mL}$ of ethanol (70\%) in a Soxhlet apparatus for 8hours.This extraction procedure was 
also used for aqueous extract. Both extracts were filtered by Whatman No.1 filter paper. Then, the filtrates were evaporated under reducing pressure using rotary evaporator at $40^{\circ} \mathrm{C}$ and the final dry extracts were stored at $4^{\circ} \mathrm{C}$ in pre sterilized air tight flasks until use to prepare $100 \mathrm{mg} / \mathrm{mL}$ from each extract [21,22].

\section{Sample collection and bacterial identification:}

A total of one hundred nasal swabs were collected from healthy food handlers male who work in different restaurants and cafeterias in Nasiriya center, Iraq, from February to June, 2015. The Sterile cotton swab sticks previously moistened with sterile normal saline and carefully inserted in both anterior nares of each person and gently rotated at least 5 times. All samples were directly inoculated on Mannitol salt agar and incubated at 37 ${ }^{\circ} \mathrm{C}$ for 24 - 48 hours. The identification of the $S$. aureus isolates was dependent on mannitol fermentation, Gram stained morphology, catalase, coagulase and DNase tests ${ }^{[23,24]}$.

Detection of methicillin resistance $S$. aureus by disc diffusion method:

All $S$. aureus isolates were tested for methicillin $(5 \mu \mathrm{g})$ and oxacillin (1 $\mu \mathrm{g})$ susceptibility by modified Kirby-Bauer method on Mueller-Hinton agar (MHA). The bacterial suspension was prepared in sterile saline by selecting the isolated colonies produced by overnight incubation on nutrient agar plate( NA ), the cell turbidity was adjusted to 0.5 McFarland standards. Subsequently, a sterile swab was dipped into the suspension and streaked on the Muller Hinton agar plate and allowed to dry for few minutes, the antibiotic discs were then placed onto the plates and incubated for 48 hours at $35^{\circ} \mathrm{C}$. The zone of inhibition around the disc was measured and interpreted according to the Clinical and Laboratory Standards Institute chart. The strains were considered resistant to both drugs if the zone size was $\leq 10 \mathrm{~mm}$. ${ }^{[25,26,27]}$.

\section{Detection of vancomycin resistance $S$.} aureus:

VRSA among MRSA isolates were detected by both agar disc diffusion and broth dilution methods (MIC).

In disc diffusion method, MuellerHinton agar plates were inoculated with the bacterial suspension which was previously adjusted to 0.5 McFarland standards. Afterward, a $30 \quad \mu \mathrm{g}$ 
vancomycin discs were aseptically placed on the surface of the agar plates within 15 minutes after inoculation, and incubated for 24 hours at $37^{\circ} \mathrm{C}$. The zone of inhibition around the disc was measured and interpreted according to the Clinical and Laboratory Standards Institute chart ${ }^{[25,26,27]}$.

In broth dilution method, the minimum inhibitory concentration (MIC) of vancomycin was determined using Muller Hinton Broth. 0.5 McFarland equivalent bacterial suspension was prepared in normal saline and spotted onto Muller Hinton plates containing different concentrations of vancomycin and incubated for 24 hours at $37^{\circ} \mathrm{C}$ and checked for any visible growth. $S$. aureus strains were considered resistant if had MIC of $\geq 16 \mu \mathrm{g} / \mathrm{ml}^{\left[{ }^{\gamma}, 2 \wedge\right]}$.

\section{Evaluation of antibacterial activity of plants:}

The modified agar welldiffusion method was used to evaluate the antibacterial activities of the extracts. $0.1 \mathrm{~mL}$ of the standardized inoculums $\left(1.5 \mathrm{x} \quad 10^{8} \mathrm{CFU} / \mathrm{ml}\right)$ of vancomycin resistant $S$. aureus (VRSA ) was aseptically spread onto the surface of sterile Mueller Hinton agar and left to dry for $30 \mathrm{~min}$. Wells of $8 \mathrm{~mm}$ in diameter were made into agar plates containing the bacterial using a sterile stainless steel borer and filled with 50 $\mu l$ of each extracts. The prepared plates were left at room temperature for 30 minutes allowing the diffusion of the extracts into the agar, then incubated at $37{ }^{\circ} \mathrm{C}$ for 24 hours. The antibacterial activity was evaluated by measuring the diameter of inhibition zone produced by the extracts against tested bacteria ${ }^{[29]}$.

\section{Statistical analysis:}

All the experimental results of were expressed as mean using Microsoft Excel 2010 software.

\section{Ethical Consideration:}

Informed consent was obtained from food handlers who work in restaurant and cafeterias after explanation the concept and dimensions of study to them

\section{RESULTS:}


In this study, out of total 100 nasal swabs collected from healthy food handlers working in the restaurants and cafeteria, $30(30 \%)$ isolates were identified as S. aureus based on morphology, Gram stain, mannitol salt agar fermentation, DNase ,catalase and coagulase tests. Among these isolates, 25 (83.3\%) were detected as MRSA based on their resistant to methicillin and oxacillin by disc diffusion method, and $20(80 \%)$ isolates of MRSA were detected as VRSA based on their resistant to vancomycin by disc diffusion method and on MIC in broth dilution method (Table 1).

Table 1 :The prevalence of Staphylococcus aureus, MRSA and VRSA among the food handlers working in the restaurants and cafeteria.

\begin{tabular}{|c|l|l|c|}
\hline No. & \multicolumn{1}{|c|}{ Bacteria } & \multicolumn{1}{|c|}{ Number of isolates } & \% \\
\hline $\mathbf{1}$ & S. aureus & 30 (out 100 isolates) & 30 \\
\hline $\mathbf{2}$ & MRSA & 25 (out of 30 S. aureus) & 83.3 \\
\hline $\mathbf{3}$ & VRSA & 20( out of 25 MRSA) & 80 \\
\hline
\end{tabular}

Cinnamon and ginger extracts showed potent antibacterial activity against VRSA. The aqueous and ethanolic extracts of cinnamon exhibited antibacterial activity with an inhibition zone diameter $15 \mathrm{~mm}$ and $18 \mathrm{~mm}$ respectively, while aqueous and ethanolic extracts of ginger showed antibacterial activity with an inhibition zone diameter $14 \mathrm{~mm}$ and $16 \mathrm{~mm}$ respectively (Table 2).

Cinnamon extracts showed higher antibacterial activity when compared with ginger extracts, whereas alcoholic extract of each plant was more effective than that of aqueous extract .

Table 2:Antibacterial activity of cinnamon and ginger extracts against VRSA.

\begin{tabular}{|l|c|c|c|}
\hline \multicolumn{4}{|c|}{ Mean diameter of inhibition zones $\mathbf{( m m )}$} \\
\hline Plant & Extract & $\begin{array}{l}\text { Aqueous } \\
\text { extract }\end{array}$ & $\begin{array}{l}\text { Ethanolic } \\
\text { extract }\end{array}$ \\
\hline Cinnamon & $\mathbf{1 0 0} \mathbf{~} \mathbf{~ g / m L}$ & 15 & 18 \\
\hline Ginger & $\mathbf{1 0 0} \mathbf{~} \mathbf{m g} / \mathbf{m L}$ & 14 & 16 \\
\hline
\end{tabular}




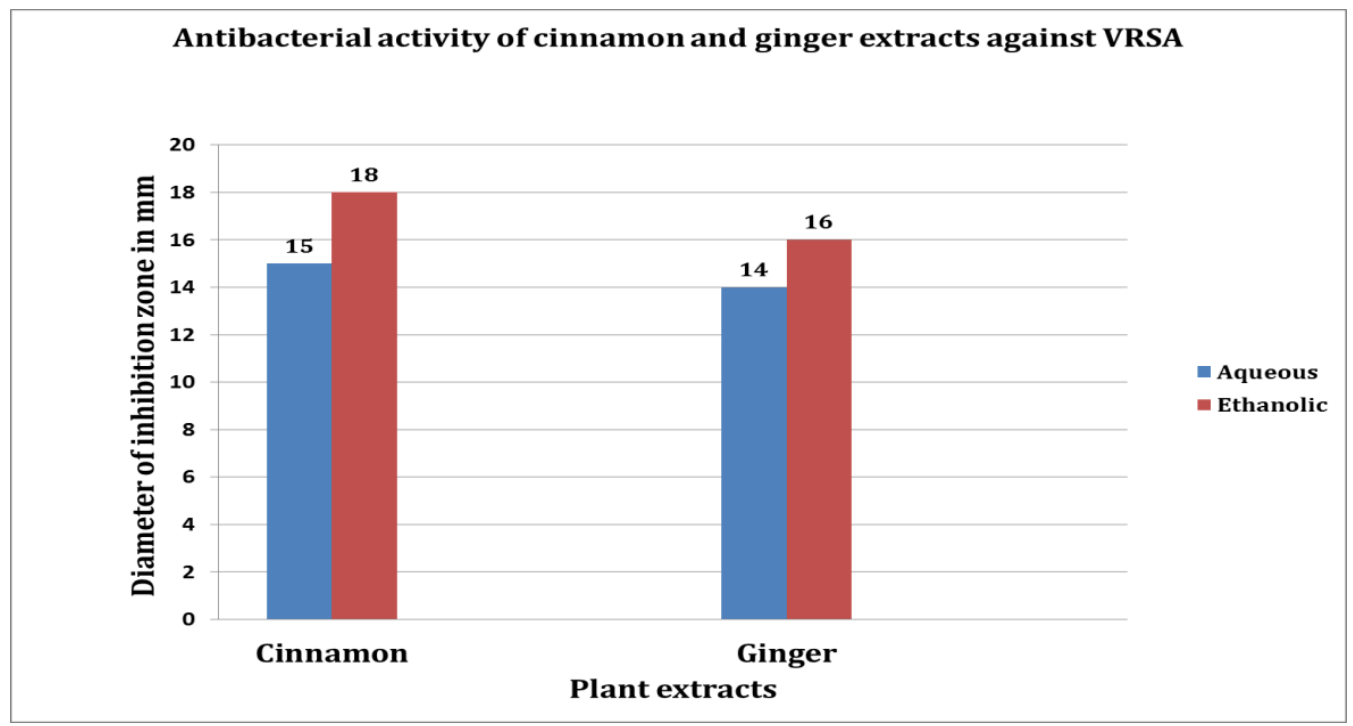

Figure 1: Antibacterial activity of cinnamon and ginger extracts against VRSA.

\section{DISCUSSION:}

Food poisoning is one of the major health problems in the world, occurs mainly in developing countries due to poor hygiene and sanitary precautions. Food handlers especially those working in restaurants and cafeteria are considered as the main sources of Staphylococcal food poisoning because they contaminate foods by their hands with $S$. aureus especially vancomycin resistant $S$. aureus which is carried in their nasal cavities . Therefore, treatment of infections caused by VRSA are often very difficult due to cross-resistance of these bacteria with a large group of antibiotics. Nevertheless, it seems reasonable to explore new sources of natural plants with antibacterial activity against them $^{[3,12]}$.

In this study, out of total 100 nasal swabs collected from healthy food handlers working in the restaurants and cafeteria, only 30 isolates $(30 \%)$ were positive for $S$. aureus. The prevalence rate of nasal carriage of $S$. aureus in our study was higher than those observed in similar studies among food handlers working in Ethiopia (20.5\%) [30], Turkey (23.1\%) ${ }^{[31]}$, USA $(23 \%)^{[32]}$, Saudia Arabia (8.5\%) ${ }^{[33]}$ and Kuwait $(26.6 \%)^{[34]}$. Nevertheless, it was lower than those obtained in studies conducted in Chilean $(65 \%)^{[35]}$, Botswana $(57.5 \%)^{[36]}$, Nigeria (60\%) ${ }^{[24]}$ and Kuwait $(53.2 \%)^{[37]}$, while it was nearly similar to that of $29 \%, 31 \%, 30.1 \%$, $29.24 \%$ which had been reported in 
Brazil, Egypt , Sudan , Iraq respectively $[38,39,40,41]$.

In present study, $25(83.3 \%)$ of the $30 \mathrm{~S}$. aureus isolates were found to be MRSA , and 20 (80\%) of the 25 MRSA isolates were found to be VRSA. Nearly similar results were obtained by other authors, they found that $28(28 \%)$ of nasal swabs from food handlers working in Samara city restaurants were positive for S. aureus, all of these isolates were resistant to methicillin(100\%), and only 5(17.85\%) of the MRSA isolates were resistance to vancomycin ${ }^{[42]}$.

Other study demonstrated that high percentage of $S$. aureus carriers was found among food handlers who worked in restaurant in Makkah, Saudi Arabia, it showed that all nasal swabs of food handlers were positive for $S$. aureus, also showed about $43 \%$ of these isolates were MRSA and $100 \%$ were VRSA $^{[43]}$. Other study showed $69.35 \%$ of collected samples were $S$. aureus, $49.04 \%$ of which were found to be MRSA, and $9.8 \%$ of MRSA were resistant to vancomycin ${ }^{[44]}$. All of these results are compatible with the of present study, while the difference in the percentages of nasal carriage of $S$. aureus, MRSA and VRSA among food handlers is due to several factors such as variation in countries, season of sample collection per year, size of samples and excessive use of antibiotics

In this study, both aqueous and ethanolic extracts of cinnamon bark exhibited antimicrobial activity against VRSA, these results agree with the results of another study which revealed that aqueous and alcoholic extracts of cinnamon bark had considerable antimicrobial activity against VRSA of urine samples from patients with urinary tract infection ${ }^{[45]}$. A study conducted in Pakistan has been shown that ethanolic extracts of cinnamon possess strongest antibacterial activity against VRSA of pus/wound samples from patients admitted to different hospitals of Pakistan ${ }^{[44]}$.

In addition, the antibacterial activity of cinnamon was also tested in previous study against VRSA isolated from wounds, blood, respiratory and urinary tract of infected patients by agar diffusion method. The results showed that cinnamon oil exhibited antibacterial activity against tested bacteria ${ }^{[46]}$,these results are in accordance with present findings.

The main mode of antibacterial action of cinnamon is damage of bacterial cell membrane, which has 
been attributed to the presence of some active constituents in their essential oils and extracts, including cinnamaldehyde , eugenol , eugenyl, linalool, benzoic acid, benzaldehyde, cinnamic acid and saponins ${ }^{[47,48,49,50]}$.

The cinnamaldehyde is highly electro-negative aromatic aldehyde interfere in biological processes involving electron transfer and react with nitrogen-containing components like proteins and nucleic acids, and therefore inhibit the growth of the microorganisms ${ }^{[51]}$. It is also exhibited antibacterial activity by their ability for inhibition the production of an essential enzyme by the bacteria and damage bacterial cell wall, this could be explained by their hydrophobicity which allowed them to partition the lipids of the bacterial cell membrane, turning them more permeable and leading to leakage of ions and other cell constituents ${ }^{[52,53,54]}$. Cinnamaldehyde is also known to inhibit amino acid decarboxylase activity ${ }^{[5]}$ and bacterial acetyl-CoA carboxylase which responsible for major antibacterial activity $^{[56]}$. In addition , cinnamaldehyde leads to inhibition of $\mathrm{N}$ - 3- oxohexanoyl-Lhomoserine lactone (3- oxo-C6-HSL) and AI-2 ,which has the potential to affect bacterial quorum sensing (QS) regulated processes ${ }^{[48,50]}$.

Previous studies reported that eugenol and eugenyl acetate are the major bioactive constituents of cinnamon bark oil. These volatile phenolic compounds are known to be either bactericidal or bacteriostatic agents, depending upon the concentration used ${ }^{[51]}$, they have ability to destroy the membranes of bacterial cells, leading to leakage of intracellular material and cell death ${ }^{[57,58]}$. Eugenol also limits the growth of microorganisms by inhibiting the production of certain enzymes needed for growth ${ }^{[59]}$.

Previous study demonstrated that cinnamon significantly decreased the production of enterotoxin $\mathrm{A}$ and enterotoxin B of S. aureus [60,61]. Furthermore, the essential oils result in immediate reduction of bacterial population and might be more effective against food borne pathogens and spoilage bacteria when applied directly on food ready to be used ${ }^{[50]}$.

In this study, both aqueous and ethanolic extracts of ginger(zingiber) rhizome exhibited antimicrobial activity against VRSA, these results are in accordance with the results of another study which reported that aqueous and 
ethanolic extracts of zingiber rhizome showed highly significant antibacterial activity against VRSA with the zone of growth inhibition $15 \mathrm{~mm}$ and $30 \mathrm{~mm}$ respectively ${ }^{[62]}$. they also agrees with another study demonstrated that alcoholic extract of zingiber had strong antibacterial activity with $17 \mathrm{~mm}$ of inhibition zone against VRSA of ear, nose and throat swabs from patients attending ENT clinic in Nigeria ${ }^{[63]}$. Our findings are also compatible with those of previous study which revealed that ethanolic of zingiber rhizomes extract had antibacterial activity against multiple-drug resistant $S$. aureus (VRSA) from patients with urinary tract and pus infections ${ }^{[64]}$. Hydro-alcoholic extracts of zingiber rhizomes extract possess strong antibacterial activity against vancomysin resistant $S$. aureus with growth inhibition zone $16 \mathrm{~mm}^{[65]}$.

The antibacterial activity has been attributed to the presence of some active constituents in the ginger rhizomes extracts like, gingerol, zingiberene, $\beta$-bisabolene, $\quad \alpha$ farnesene, shogaol, $\quad \beta$ sesquiphellandrene and $\alpha$-curcumene [22].

Gingerol and other phenolic compound which are protein denaturing agents lead to swelling and rupture of the bacterial cell membrane by changing their permeability, which in turn caused damage of cytoplasmic membrane and release of cell materials, like nucleic acid, metabolites and ions. In addition, most of phenolic compounds are metal chelators that attach to the active site of the metabolic enzymes, reducing enzyme activities and therefore slowing bacterial metabolism and reproduction ${ }^{[66]}$.At the same time, the $\beta$-bisabolene, $\alpha$ farnesene and sesquiphelandrene of ginger compounds cause disruption of the cytoplasmic membrane and coagulation of the cell contents ${ }^{[67]}$.

Several studies indicated that the antimicrobial potency of ginger mainly caused by the presence of oxygenated mono- and sesquiterpenes, hydrocarbons. These compounds attack the cell walls and cell membranes and affecting their permeability leading to release of intracellular constituents (e.g. ribose, Na glutamate), also interfere with membrane functions including electron transport, nutrient uptake, protein, nucleic acid synthesis and enzyme activity leading to inhibition of bacterial pathogens ${ }^{[68,69]}$.

Other authors have suggested that antimicrobial components of the ginger extracts (terpenoids and 
alkaloids) interact with enzymes and proteins of the microbial cell membrane causing its disruption to disperse a flux of protons towards cell exterior which inhibit enzymes necessary for amino acids biosynthesis and induces bacterial $\operatorname{death}^{[70,71]}$.

previous study reported that essential oils of zingiberaceae family can provoke depolarization of the mitochondrial membranes by decreasing the membrane potential, affecting ionic $\mathrm{Ca}^{++}$cycling and other ionic channels, reducing the $\mathrm{pH}$ gradient, affecting the proton pump and ATP pool. They change the fluidity of membranes, which become abnormally permeable resulting in leakage of radicals, cytochrome $\mathrm{C}$, calcium ions and proteins, finally leads to bacterial death $^{[72]}$.

In this study, the ethanolic extracts of each plant had potent antibacterial activity than that of aqueous extracts, which compatible with other studies demonstrated that ethanolic extracts of cinnamon and ginger possesses a higher inhibitory activity against the tested organisms than that of the aqueous extracts ${ }^{[71]}$. Because ethanol is an organic solvent and dissolve organic compounds better, hence liberate active components required for antimicrobial activity ${ }^{[73,74]}$.

In conclusion, this study has revealed a relatively high prevalence rate of VRSA nasal carriage among food handlers working in the restaurants and cafeteria.Cinnamon and ginger extracts had potent antibacterial activity toward VRSA, therefor can be used as a natural food preservatives and to treat infections caused by VRSA .

\section{REFERENCES:}

1. Habeeb A, Hussein NR, Assafi MS ,Al-Dabbagh SA. Methicillin resistant Staphylococcus aureus nasal colonization among secondary school students at Duhok city-Iraq. Journal of Microbiology and Infectious Diseases 2014 ; 4 (2): 59-63.

2. 2-Noor-Ariza AM, MohammadFaid AR, Shuhaimi M, Syafinaz AN, Hamat RA, Malina O. Staphylococcus aureus in food and nares of food handlers in Kuala Pilah, Malaysia. Pertanika Journal of Tropical agricultural Science 2012; 35 (4): 853862.

3. Çepoglu H, Vatansever L, Oral NB. Isolation of Staphylococci from food handlers and investigation of their enterotoxigenicity and susceptibility to 
Web Site: https://jmed.utq.edu.iq

some antibiotics. Kafkas Univ Vet Fak

Derg.2010; 16 (Suppl-A): S1-S5.

4. da Silva Sdos S, Cidral TA, Soares

MJ, de Melo MC. Enterotoxin-encoding genes in Staphylococcus spp. from food handlers in a University restaurant. Foodborne

Pathog

Dis.2015;12(11):921-925.

5. Aliyu AB, Musa AM, Abdullahi MS, Oyewale AO. Activity of plant extracts used in northen Nigerian traditional medicine against methicillin resistant Staphylococuus aureus (MRSA). Nigerian J of Pharmaceutical Sciences.2008; 7 (1): $1-8$.

6. Pesavento G, Ducci B, Comodo N, Nostro AL. Antimicrobial resistance profile of $S$. aureus isolates from raw meat: a research for MRSA. Food Control 2007;18:196-200.

7. Dhanalakshmi TA, Umapathy BL, Mohan DR. Prevalence of methicillin, vancomycin and multidrug resistance among Staphylococcus aureus. J.Clin.Diag.Res.2012;1:1-4.

8. Shahriar M, Shahid S, Katha KK, Nasreen W, Bhuiyan MA. Vancomycin sensitivity of Staphylococcus aureus isolates from clinical patients in Dhaka City, Bangladesh. Bangladesh Pharma. J.2012; 15:1-4.

9. Kaleem F, Usman J, Sattar A, Amanat ST, Hassan A, Omair M, et al.
Current status of vancomycin susceptibility against methicillin resistant Staphylococcus aureus (MRSA) strains: A study at two tertiary care hospitals of Pakistan. Afr. J. Microbiol. Res.2012; 6: 6243-6246.

10. Mandal S, DebMandal M, Saha K, Pal Nishith K. In vitro antibacterial activity of three Indian spices against methicillin-resistant Staphylococcus aureus. Oman Medical Journal 2011; 26 (5):319-323.

11. Kumar A, Kaushal V, Patil S, Payal C, Kumar A. Antibacterial potential of some natural food preservatives against Staphylococcus aureus isolated from various food samples of Himachal Pradesh (India).World J of Science and Technology 2011;1(10):48-53.

12. Abd El-Aziz DM, Ali SFH. Antibacterial activity of extracts of some spices on growth of methicillin resistant Staphylococcus aureus strains. Annals. Food Science and Technology 2013;14( 2): 227-229.

13. Jakhetia V, Patel R, Khatri P, Pahuja N, Garg S, Pandey A, et al. Cinnamon: A pharmacological review. JASR. 2010;1:19-23.

14. Al-Jiffri O, El-Sayed Z, Al-Sharif F. Urinary tract infection with Esherichia coli and antibacterial 
activity of some plants extracts. Int. J. Microbiol. Res. 2011;2:1-7.

15. Brierley SM, Kelber O.Use of natural products in gastrointestinal therapies. Curr.

Opin.

Pharmacol. 2011;11:604-611.

16. Khasnavis S, Pahan K. Sodium benzoate, a metabolite of cinnamon and a food additive, upregulates neuroprotective parkinson disease protein DJ-1 in astrocytes and neurons. J. Neuroimmune Pharmacol. 2012;7:424-435.

17. Van Wyk BE, Wink M. Medicinal plants of the World, in: An Ilustrated Scientific Guide to Important Medicinal Plants and their uses, Medpharm Publisher, Briza Publications Pretoria, South Africa 2004, pp. 344-370.

18. Ansari MN, Bhandari U, Pillai KK. Ethanolic Zingiber officinale R. extract pretreatment alleviates isoproterenolinduced oxidative myocardial necrosis in rats. Indian J Exp Biol. 2006;44:8927.

19. Manju V, Nalini N. Effect of ginger on bacterial enzymes in 1, 2dimethylhydrazine induced experimental colon carcinogenesis. Eur J Cancer Prev.2006;15:377-83.

20. Akinloye OL, Somade OT, Akindele AS, Adelabu KB, Elijah FT, Adewumi OJ. Anticlastogenic and hepatoprotective properties of ginger (Zingiber Officinale) extract against nitrobenzene-induced toxicity in rats. ROM. J. BIOCHEM.2014; 51(1): 3-15. 21. Eidi A, Mortazavi P, Bazargan M, Zaringhalam J. Hepatoprotective activity of cinnamon ethanolic extract against ccl4-induced liver injury in rats. EXCLI J 2012;11:495-507.

22. Choudhari SS, Kareppa BM. Identification of bioactive compounds of Zingiber Officinale Roscoe rhizomes through gas chromatography and mass spectrometry. Int J Pharm Res Dev.2013; 5: 16-20.

23. Cheesbrough M. Biochemical tests to identify bacteria. District Laboratory practices in tropical Countries part 2006;2: 62-70.

24. Eke SO, Eloka CCV, Mgbachi N, Nwobodo HA, Ekpen-Itamah U J. Nasal carriage of Staphylococcus aureus among food handlers and restaurant workers in ekpoma edo state, Nigeria . International Journal of Community Research.2015; 4(1): 7 - 14.

25. Clinical and Laboratory Standards Institute. Performance standards for antimicrobial susceptibility testing; twenty first informational supplement. Wayne, PA: Clinical and Laboratory Standards Institute; 2011. (CLSI document M100-S21). 
26. Schweizer M, Ward M, Cobb S, McDanel J, Leder L, Wibbenmeyer L, et al. The epidemiology of methicillinresistant Staphylococcus aureus on a burn trauma unit. Infect Control Hosp Epidemiol.2012; 33(11): 1118-1125.

27. Reddy PS, John MS, Devi PV,Reddy BSP. Detection of vancomycin susceptibility among clinical isolates of MRSA by using minimum inhibitory concentration method. Int J Res Med Sci.2015;3(6):1378-1382.

28. Loomba PS, Taneja J, Mishra B. methicillin and vancomycin resistant $S$. aureus in hospitalized patients. J Glob Infect Dis.2010; 2(3): 275-283.

29. Unnisa N, Tabassum H, Ali MN, Ponia K. Evaluation of antibacterial activity of five selected fruits on bacterial wound isolates. Int $\mathrm{J}$ Pharm Bio Sci . 2012; 3(4): 531 - 546.

30. Dagnew M, Tiruneh M, Moges M, Tekeste F. Survey of nasal carriage of Staphylococcus aureus and intestinal parasites among food handlers working at Gondar University, Northwest Ethiopia. BMC Public Health 2012; 12:837.

31. Simsek Z, Koruk I, Kopur AC, Gurses G. Prevalence of Staphylococcus aureus and intestinal parasites among food handlers in Sanliurfa, Southeastern
Anatolia. J. Public Health Manag. Pract 2009; 15:518-523.

32. Mainous CAG, Hueston WJ, Everett CJ, Diaz VA. Nasal carriage of Staphylococcus aureus and methicillinresistant S. aureus in the United States. Ann. Fam. Med 2006; 4:132-137.

33. Dablool AS, Al-Ghamdi AA. Enterotoxigenicity of Staphylococcal aureus isolated from food handlers during Hajj season in Saudi Arabia. Open Journal of safety Science and Technology 2011; 1: 75-78.

34. Al-Bustan MA, Udo EE, Chugh TD. Nasal carriage of enterotoxinproducing Staphylococcus aureus among restaurant workers in Kuwait city. Epidemiol. Infect.1996; 116: 319322.

35. Soto A, Saldias ME, Oviedo P, Fernandez M. Prevalence of Staphylococcus aureus among food handlers from a metropolitan university in Chile. Rev. Med. Chil.1996; 124: 1142-1146.

36. Loeto D, Matsheka MI, Gashe BA. Enterotoxigenic and antibiotic resistance determination of Staphylococcus aureus strains isolated from food handlers in Gaborne, Botswana. J. food Prot.2007; 70: 27642768. 
37. Udo EE, Al-Mufti S, Albert MJ. The prevalence of antimicrobial resistance and carriage of virulence genes in Staphylococcus aureus isolated from food handlers in Kuwait City restaurants. BMC Research Notes 2009; 2:108.

38. Carmo LS, Dias RS, Linardi VR, Sena MJ, Dos Santos DA. An outbreak of staphylococcal food poisoning in the municipality of Passos, Minas Geralis, Brazil. Braz. Arch. Biol. Technol 2003; 46: 581-586.

39. El-Shenawy M, El-Hosseiny L, Tawfeek M, El- Shenawy M, Baghdadi $\mathrm{H}$, Saleh $\mathrm{O}$, et al. Nasal carriage of enterotoxigenic Staphylococcus aureus and risk factors among food handlersEgypt. Food and Public Health 2013; 3(6): 284-288.

40. Saeed HA ,Hamid HH. Bacteriological and parasitological assessment of food handlers in the Omdurman Area of Sudan. J. Microbiol. Immunol. Infect.2010; 43:70-73.

41. Saeed AY. Enterotoxigenicity and antibiogram profile of Staphylococcus aureus isolated from food handlers in restaurants and cafeterias in Duhok city, Iraq. Journal of American Science 2015;11(3):21-24.

42. Alsamarai AM, Abbas HM, Atia QM. Nasal carriage of methicillin resistant staph aureus in food provider in resturant at samara city. World Journal of Pharmacy and Pharmaceutical Sciences. 2015; 4(6): $50-58$.

43. Abulreesh HH, Organji SR.The prevalence of multidrug-resistant Staphylococci in food and the environment of Makkah, Saudi Arabia. Research Journal of Microbiology 2011; 6 (6): 510-523.

44. Liaqat F, Sheikh AA, Nazir J, Hussain T, Rabbani M, Shaheen AY, et al. Isolation identification and control of vancomycin resistant Staphylococcus aureus. Pak. J. Pharm. Sci. 2015;28(3):997-1004.

45. Jyothiprabha V, Venkatachalam P. Antibacterial activity of spices against multi drug resistant bacteria isolated from urinary tract infection. Int J Pharm Bio Sci . 2015; 6(4): 426 - 431.

46. Hassanein WA, EL- Zawahry YA, Reda FM, Abd El- Rahman RA. Molecular and microbiologic al studies on vancomycin resistant staphylococcus aureus (VRSA) strains isolated from burned patients. Egypt. J. Exp. Biol. 2013;9(2): 219 - 231.

47. Ramos-Nino ME, Cliford MN ,Adams MR. Quantitative structure activity relationship for the effect of benzoic acid, cinnamic acids and 
benzaldehydes on Listeria monocytogenes. J. Appl. Microbiol. 1996; 80: 303-310.

48. Niu C, Afre S ,Gilbert ES. Sub inhibitory concentrations of Cinnamaldehyde interfere with quorum sensing. Lett. Appl. Microbiol.2006; 43: 489-494.

49. Venkatachalam1 P, Jyothiprabha V. Phytochemical screening and antibacterial activities of cinnamon against vancomycin resistant enterococcus., International Journal of Science and Research 2016; 5 (9):309312.

50. Salem AM, Zakaria EM ,Abd El Raheem KA. Efficiency of some essential oils in control of methicillin resistant Staphylococcus Aureus (MRSA) in minced beef. Benha Veterinary Medical Journal.2017;32(1): 177-183.

51. Gupta C, Garg AP, Uniyal RC, Kumari A. Comparative analysis of the antimicrobial activity of cinnamon oil and cinnamon extract on some foodborne microbes. Afr. J. Microbiol. Res. 2008;2(9): 247-251.

52. Ultee A, Bennik MHJ. ,Moezelaar R.The phenolic hydroxyl group of carvacrol is essential for action against the food-borne pathogen Bacillus cereus," Applied and Environmental Microbiology 2002;(4):1561-1568.

53. Burt S. "Essential oils: their antibacterial properties and potential applications in foods - a review, " International Journal of Food Microbiology 2004; 94( 3): 223-253.

54. Hussein HA, Abaas IS ,Ali RH. Antibacterial activities of cinnamon zelanicum syzygium aromaticum essential oil. Int J Pharm Pharm Sci.2014; 6( 5):165-168.

55. Wendakoon CN ,Sakaguchi M. Inhibition of amino acid decarboxylase activity of Enterobacter aerogenes by active components of spices. J. Food Prot.1995;58:280-283.

56. Meades GJ, Henken RL, Waldrop GL, Rahman MM, Gilman SD, Kamatou GP, et al. Constituents of cinnamon inhibit bacterial acetyl CoA carboxylase. Planta Med 2011;76:15701575.

57. He F, Yang Y, Yang G, Yu LJ. Studies on antibacterial activity and antibacterial mechanism of a novel polysaccharide from Streptomyces Virginia H03. Food Control.2010; 21: 1257-1262.

58. Adisakwattana S, Lerdsuwankij O, Poputtachai U, Minipun A., Suparpprom C. Inhibitory activity of cinnamon bark species and their 
combination effect with acarbose against intestinal $\alpha$-glucosidase and pancreatic $\alpha$ - amylas. Plant Foods Hum Nutr.2011; 66: 143-148.

59. Parasa LS, Tumati SR, Prasad C ,Kumar LCA. In vitro antibacterial activity of culinary spices aniseed, star anise and cinnamon against bacterial pathogens of fish. Int. J. Pharmacy and Pharmaceutical Sciences 2012; 4: 667670.

60. Fyfe L. Antimicrobial agents and chemotherapy. Journal of Medical Microbiology 2004; 53(10) : 10231027.

61. Al-dhaher ZA. The antibacterial activity of aqueous extract of cinnamon and clove against Staphylococcus aureus. Journal of Al-Nahrain University 2008;11(2):131-135 .

62. EL-Zawahry YA, Reda FM ,Azazy WM. Synergistic effects of combination treatment between certain plant extracts and some antibiotics on the resistance of pathogenic bacteria against some common antibiotics. Life Sci J.2013;10(4):3477-3489.

63. Mohammed Y, Dr. Mukhtar MD, Orah SA. Synergistic activity of garlic, ginger and moringa on ear, nose and throat associated fungi and vancomycin resistant cocci at aminu kano teaching hospital, Kano, Nigeria. World Journal of Pharmaceutical and Medical Research 2017; 3(4): 01-10.

64. Karuppiah P, Rajaram S. Antibacterial effect of Allium sativum cloves and Zingiber officinale rhizomes against multiple-drug resistant clinical pathogens. Asian Pac J Trop Biomed.2012; 2(8): 597-601.

65. Azadpour $\mathrm{M}$, Azadpour $\mathrm{N}$, Bahmani M, Hassanzadazar $\mathrm{H}$, Rafieian-Kopaei M, Naghdi N. Antimicrobial effect of Ginger (Zingiber officinale) and mallow (Malva sylvestris) hydroalcholic extracts on four pathogen bacteria. Der Pharmacia Lettre.2016; 8 (1):181-187.

66. Ahmed SA, Jabbar II ,Abdul wahed HE. Study the antibacterial activity of Zingiber officinale roots against some of pathogenic bacteria. Al- Mustansiriya J. Sci.2012; 23(3):63-70.

67. Poeloengan M. The effect of red ginger (Zingiber officinale Roscoe) extract on the growth of mastitis causing bacterial isolates. Afr. J. Microbiol. Res.2011; 5(4):382-389.

68. Singh G, Kapoor IP, Singh P, de Heluani CS, de Lampasona MP,Catalan CA. Chemistry, antioxidant and antimicrobial investigations on essential oil and oleoresins of Zingiber Officinale. Food and Chem Toxicol.2008; 46: 3295-3302. 
69. Hasan HA, Rasheed Raauf AM, Abd Razik BM, Rasool Hassan BA. Chemical composition and antimicrobial activity of the crude extracts isolated from Zingiber Officinale by different solvents. Pharmaceut Anal Acta.2012; 3:184.

70. Malu SP, Obochi GO, Tawo EN, Nyong BE. Antibacterial activity and medicinal properties of ginger (Zingiber officinale). Global J Pure Appl Sci.2008; 15:365-368.

71. Akintobi OA, Onoh CC, Ogele JO, Idowu AA, Ojo OV ,Okonko IO. Antimicrobial activity Of Zingiber Officinale (Ginger) extract against some selected pathogenic bacteria. Nature and Science 2013;11(1):7-15.

75. .
72. Tripathi M, Chawla P, Upadhyay R, Trivedi S. Essential oils from family Zingiberaceae for antimicrobial activity- a review. Int $\mathrm{J}$ Pharm Bio Sci.2013; 4(4): 149 - 162.

73. Senhaji O, Faid M ,Elyachioui M. Inhibitory effect of cinnamon extracts on bacterial antibio-resistant strains. Biologie \& Santé.2004;4(2):1-10.

74. Yassen D ,Ibrahim AE. Antibacterial activity of crude extracts of ginger (Zingiber Officinale Roscoe) on Escherichia coli and Staphylococcus aureus: a study in vitro. Indo American Journal of Pharmaceutical Research 2016;6 (6):5830-

5835 


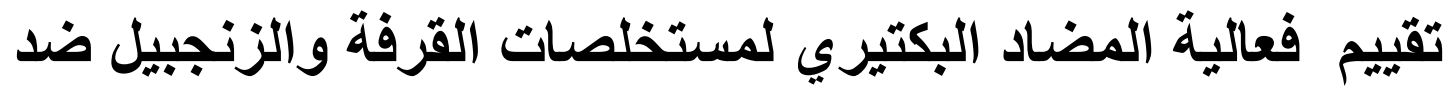

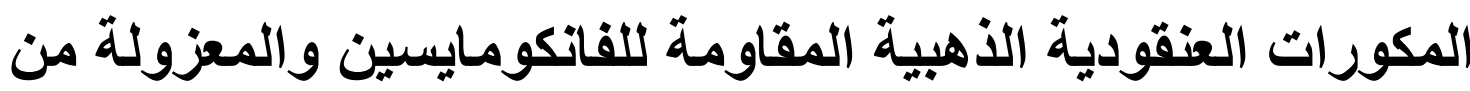

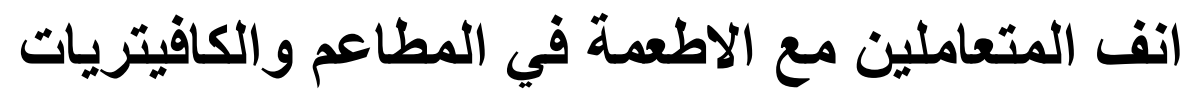

\author{
عدي عبد الرضا حسين
}

دكتوراه ادوية ،فرع العلوم المختبرية السريرية ،كلية الصيدلة، جامعة ذي قار، العراق

$\ddot{d}$ الخلاصد

يعتبر الاشخاص المتعاملين مع الاطعمة مصدر ا رئيسيا للتسمم الغذائي بالمكورات العنقودية في البلدان المتقدمة. الهُف: تهدف هذه الدر اسة الى تحديد مدى انتشار المكورات العنقودية الذهبية المقاومة للفانكومايسين في تجويف انف الاشخاص المتعاملين مع الاطعمة في المطاعم والكافتيريات ،وتهدف ايضا الى تقييم فعالية المضاد البكتيري

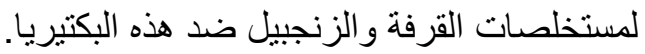

طريقة العمل: تم جمع · · مسحة من تجويف انف الاشخاص المتعاملين مع الاطعمة ، وتم زراعتها في أوساط زرعية للكثف عن المكورات العنقودية الذهبية، المكورات العنقودية الذهبية المقاومة للميثيسيلين و المكور ات العنقودية الذهبية المقاومة للفانكومايسين. تم تحضير المستخلصات المائية والايثانولية لكل نبات باستخدام جهاز السوكسليت و استخدمت طريقة الاكار لتحديد فعالية المضاد البكنيري لهذه المستخلصات ضد المكورات العنات العنقودية الذهبية المقاومة

للفانكو مايسين.

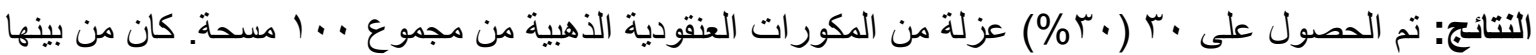

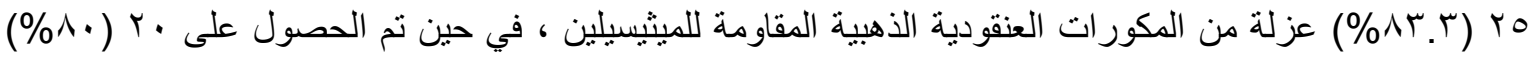

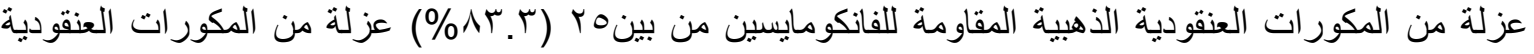
الذهبية المقاومة للميثيسيلين..

أظهرت المستخلصات النباتية نشاطا فعالا عاليا ضد المكورات العنقودية الذهبية المقاومة للفانكومايسين. كما بينت

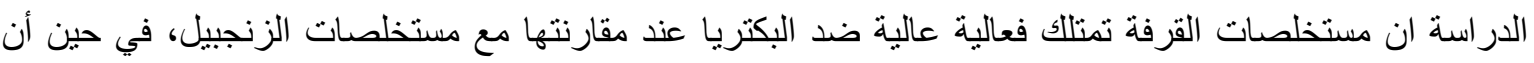
المستخلص الإيثانولي لكل نبات كان أكثر فعالية من المستخلص المهائي.

الخلاصة: وجدت هذه الدراسة ازدياد نسبي في معدل انتشار المكورات العنقودية الذهبية المقاومة للفانكومايسين في تجويف انف الاشخاص المتعاملين مع الاطعمة. كذلك وضحت بان القرفة والزنجبيل هما مصدرا غنيا للمركبات المضادة للميكروبات التي يمكن أن تستخدم كمواد طبيعية حافظة للأغذية ولمعالجة الالتهابات التي تسببها هذه

البكتيريا.

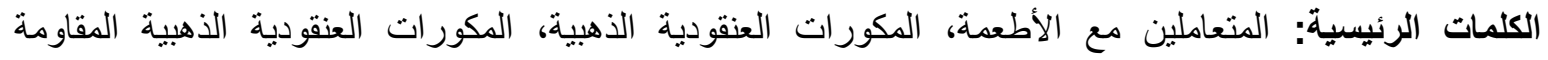
للميثيسيلين ،المكورات العنقودية الذهبية المقاومة للفانكومايسين ، نقل البكتريا بواسطة التجويف الأنفي، القرفة، ،الزنجبيل ،فعالية المضاد البكتيري. 